ratchet. If the opening bar of the cuff is not applied accurately this could result in a blow to the radial styloid, which lies superficially. Sudden compression inside the metal ring may also be a causal mechanism.

Though further narrowing of the cuff after application may be prevented by tripping a small spring, this is not always possible in the circumstances of an arrest. The handcuffs may tighten if the detainee continues to struggle, resulting in further compression.

We believe that the injuries described were caused by handcuffs and conclude that a claim of pain, weakness, or altered sensation after the detention of a patient in handcuffs should not be dismissed. Consideration should also be given to preventing such injuries.

1 Dorfman LJ, Jayaram AR. Handcuff neuropathy. FAMA 1978;239:957.

2 Massey EW, Plett AB. Handcuffs and cheiralgia paresthetica. Neurology 1978;28:1312-3.

3 Appel H. Handcuff related cheiralgia paresthetica. Neurology 1979;29:908-9. 4 Smith MS. Handcuff neuropathy. Ann Emerg Med 1981;10:668.

Levin RA, Feltenshal G. Handcuff neuropathy: two unusual cases. Arch Phys Med Rehab 1984;65:41-3.

(Accepted 5 April 1988)

\section{Employment outside the NHS of doctors registered in the United Kingdom}

\section{J P Nicholl, B T Williams}

Medical Care Research Unit, Department of Community Medicine, University of Sheffield, Sheffield S10 2RX J P Nicholl, MSC, senior statistician

B T Williams, FFCM, professor

Correspondence to: $\mathrm{Mr}$ Nicholl. yearly by health authorities.
Data on the occupation of all civilian doctors were held on the Civilian Doctors' Career Index until it was discontinued in 1982. The Department of Health and Social Security's database on medical manpower now consists only of registration data supplied by the General Medical Council and job information returned

The lack of information makes accurate planning of medical manpower in the United Kingdom difficult. Thus a recent report of the Advisory Committee for Medical Manpower Planning estimated many quantities from scant information, ${ }^{1}$ and the consultative document Hospital Medical Staffing: Achieving a Balance $^{2}$ had been both criticised and defended, partly because of differing estimates of where current graduates from the United Kingdom end up. We report findings on the numbers and activities of currently registered doctors working in the United Kingdom outside the NHS.

\section{Doctors, methods, and results}

A stratified random sample of 1822 of the 43624 doctors registered on the GMC's principal list in July 1986 whose names were not on the 1985 DHSS census files of doctors working in the NHS were sent a questionnaire asking about their occupations in 1985 and 1986 and their last post in the NHS. Information was received from $1534(84 \%)$ of the doctors and the occupations of a further 55 doctors were taken as those mentioned in the Medical Directory. ${ }^{3}$

Of the 1556 doctors in the sample whose status on 30 September 1986 was known, 488 were retired and 359 were working for the NHS. Of the remaining doctors, 280 were in medical employment in the United Kingdom outside the NHS. After weighting to account for stratification of the sample and slight differences in rates of response within these strata, we estimated that

Numbers of respondents and estimated numbers (percentages) of doctors in medical employment in the United Kingdom outside the NHS in 1986

\begin{tabular}{lccccc}
\hline & & \multicolumn{4}{c}{ Estimated No (\%) of doctors } \\
\cline { 3 - 6 } Sector & $\begin{array}{c}\text { No of } \\
\text { respondents } \\
(\mathrm{n}=280)\end{array}$ & $\begin{array}{c}\text { Employed } \\
\text { full time } \\
(\mathrm{n}=4340)\end{array}$ & $\begin{array}{c}\text { Employed } \\
\text { part time } \\
(\mathrm{n}=2350)\end{array}$ & $\begin{array}{c}\text { Not } \\
\text { known } \\
(\mathrm{n}=270)\end{array}$ & $\begin{array}{c}\text { Total } \\
(\mathrm{n}=6960)\end{array}$ \\
\hline Armed forces & 58 & $1160(27)$ & $140(6)$ & 20 & $1320(19)$ \\
Other public service or industry & 88 & $820(19)$ & $1110(47)$ & 200 & $2130(31)$ \\
Pharmaceutical industry & 25 & $480(11)$ & & 20 & $500(7)$ \\
Other private industry & 23 & $360(8)$ & $130(6)$ & & $490(7)$ \\
Private medical practice & 64 & $1110(26)$ & $800(34)$ & & $1910(27)$ \\
University (without NHS contract) & 7 & $120(3)$ & $40(2)$ & 30 & $160(2)$ \\
Other & 15 & $290(7)$ & $130(6)$ & & $450(7)$ \\
\hline
\end{tabular}

6960 (95\% confidence interval 6170 to 7730$)$ doctors were so employed (table). Of these, 990 (14\%).were working in private industry, and $1910(27 \%)$ in private medical practice. Of those working full time 1950 $(45 \%)$ were in private practice or private industry. Of all the 6960 doctors, $4970(71 \%)$ were trained in the United Kingdom and under 65 when they left their last post in the NHS.

Most $(5840(84 \%))$ were men, though nearly $30 \%$ of those aged 30-39 were women. Only 26 respondents reported being unemployed at the time of the survey, which, after allowing for stratification and so on, was less than $1 \%$ of the "active stock" of doctors in the United Kingdom.

\section{Comment}

Although nearly half the estimated 6960 doctors medically employed in the United Kingdom outside the NHS in 1986 were working in the private sector, the number of doctors under 65 and working full time in the private sector represented only $2 \%$ of all medically employed doctors in the United Kingdom in 1986. This is much less than the $7 \cdot 1 \%$ of whole time equivalent qualified nurses working full time in independent hospitals and nursing homes in $1985 .{ }^{4}$ Consequently, there may be less pressure on the private sector to contribute to the costs of training doctors than to those of training nurses.

Other longitudinal studies have examined the careers of female doctors in more detail. ${ }^{5}$ Nevertheless, as the proportion of female doctors medically employed outside the NHS was lower than that of male doctors except in the age range 30-39 it seems that some female doctors with children may be actively seeking employment outside the NHS, perhaps because the NHS is not providing adequate arrangements for them.

Medical employment in this country cannot reasonably be assumed to be in a steady state, hence our data cannot be used to comment on flows in and out of the NHS. Nevertheless, the data indicate, as might be expected, a substantial loss of doctors from the NHS to medical employment outside the NHS in the United Kingdom.

We thank Mr M Roberts and his colleagues at the DHSS for their help in compiling the data, and our colleagues Ms Maria Platts and Lynne Addis for their help with the study. The project was funded by the DHSS, which maintains this unit with the Trent Regional Health Authority. The views expressed in this paper are, however, ours alone.

\footnotetext{
1 Advisory Committee for Medical Manpower Planning. Report. London: DHSS 1985.

2 Department of Health and Social Security, Joint Consultant Commitree Chairman of Regional Health Authorities. Hospital medical staffing: achieving a balance. London: DHSS, 1986.

3 The Medical Directory. London: Churchill Livingstone, 1985 and 1986.

4 Thomas KJ, Nicholl JP, Williams BT. A study of the movement of nurses and

Thomas KJ, Nicholl JP, Williams BT. A study of the movement of nurses and
nursing skills between the NHS and the private sector in England and Wales. nursing skills between the NH

5 Ward AMW. Careers of medical women. Br Med f 1982;289:31-3.

(Accepted 22 March 1988)
} 